\title{
A voluntariedade da colaboração premiada e sua relação com a prisão processual do colaborador
}

\author{
Defendant's free will in legal collaboration \\ and its relation with pre-trial detention
}

\section{Antonio Henrique Graciano Suxberger ${ }^{\mathbf{1}}$}

Professor do Programa de Pós-Graduação do UniCEUB (Brasília/DF). Professor do Máster da Universidade Pablo de Olavide (Sevilha/Espanha) e Universidade Internacional da Andaluzia. Doutor em Direito. antonio.suxberger@uniceub.br

http://lattes.cnpq.br/9136957784681802

http://orcid.org/0000-0003-1644-7301

Gabriela Starling Jorge Vieira de Mello 2

Graduada em Direito pela UFMG. Especialista pela FESMPDFT (Brasília/DF).

gabistarling@hotmail.com

http://lattes.cnpq.br/3709549236300348

Dittp://orcid.org/0000-0001-6639-0695

Resumo: A colaboração premiada, meio de obtenção de prova utilizado no enfrentamento das organizações criminosas, exige voluntariedade do colaborador que celebra o acordo jurídico-processual. $\mathrm{Na}$ aferição da voluntariedade, muitas são as críticas dirigidas ao acordo celebra-

1 Professor do Programa de Mestrado e Doutorado em Direito do Centro Universitário de Brasília (UniCEUB). Professor do Máster Oficial em Direitos Humanos, Interculturalidade e Desenvolvimento da Universidade Pablo de Olavide (Sevilha, Espanha) e Universidade Internacional da Andaluzia. Professor associado à linha de investigação "Derechos Humanos y Desarrollo" do programa de doutorado em Ciências jurídicas e políticas da Universidade Pablo de Olavide. Professor da Fundação Escola Superior do MPDFT (FESMPDFT) e da Escola Superior do Ministério Público da União (ESMPU). Doutor e Mestre em Direito. Promotor de Justiça no Distrito Federal.

2 Graduada em Direito pela Universidade Federal de Minas Gerais. Especialista em "Ordem Jurídica e Ministério Público" pela Fundação Escola Superior do Ministério Público do Distrito Federal e Territórios. 
do nos casos em que o colaborador se encontre preso. Esses dois institutos - prisão preventiva e colaboração premiada-, embora não possuam relação de causa e efeito, não raro são vistos intrinsecamente ligados na prática. $\mathrm{O}$ artigo busca avaliar a voluntariedade nos casos em que imposta ao pretenso colaborador prisão no curso da persecução e os principais argumentos favoráveis e contrários à legitimidade do acordo firmado pelo colaborador preso. Propõe, ao final, a construção de uma relação específica e bem delineada entre prisão processual e colaboração premiada. A identificação de problemas pontuais não implica a construção de um problema estrutural no desenho do instituto da colaboração premiada, sob pena de serem alcançadas soluções superficiais, que acabariam por fragilizar, ainda mais, a situação do acusado preso. Quanto à metodologia, o artigo se vale do conceito de "caso" penal e utiliza revisão bibliográfica e análise documental do tema eleito.

Palavras-chaves: Colaboração premiada; Prisão preventiva; Caso penal; Voluntariedade; Coação.

ABstRACt: The legal coll laboration, a type of evidence used on organized crime prosecutions, demands free will of the defendant.Appraising the defendant's free will, many critics cover the deals made with an arrested defendant during the negotiation of the legal collaboration. These two institutes legal collaboration and pre-trial detention -, although they do not present themselves as a cause-effect relation, commonly are approached in practice as associated. This essay intends to evaluate the defendant's free will during pre-trial detention and the legal collaboration's bargaining. It asserts a strict and clear relation between pre-trial detention and the legal collaboration bargaining. Identifying occasional problems do not imply the conclusion on the existence of a structural problem to legal collaboration institute. This consideration is relevant to avoid superficial solutions that could fragilize even more the held defendant. Methodologically, from a literature review and document analysis about the subject, the paper clarifies what is a "criminal case" and what it means to the study.

KeYwords: Legal collaboration; Pre-trial detention; Criminal case; Free will of the defendant; Coercion.

SumÁrıo: Introdução. 1. Polêmicas e problematização. 2.Projeto de Lei n. 4.372/2016. 3. A relação entre prisão preventiva e colaboração - invenção ou realidade? 3.1. Voluntariedade. 3.2. Os requisitos da prisão preventiva. 3.3. Eticidade. 4. Possíveis soluções para o problema. Conclusões. Referências. 


\section{INTRODUÇÃo}

A colaboração premiada e sua repercussão no ordenamento jurídico pátrio é tema que merece estudo detido e aproveitamento crítico dos casos recentes que se valem de sua incidência. Embora não se trate de uma figura nova no ordenamento jurídico ${ }^{3}$, é inegável que, recentemente, o instituto se popularizou. Dentro ou fora do meio jurídico, sempre são encontradas opiniões e, principalmente, críticas sobre a colaboração premiada. Em sede acadêmica, analisa-se o instituto desde o seu aspecto mais amplo, como ferramenta do direito penal negocial ${ }^{4}$, até as suas especificidades, como os prêmios legais oferecidos ao colaborador ${ }^{5}$.

3 "Conquanto em tempos hodiernos se empreste nova roupagem à colaboração premiada, a par de se criarem diversos termos para nominá-la com pequenas nuances de significado, bem como outras sejam as razões de política criminal que justificam a sua adoção pelo ordenamento jurídico, localiza-se sua previsão em diploma normativo do princípio do século XVII, as Ordenações Filipinas, cuja vigência se estendeu no território brasileiro de 1603 a dezembro de 1830, quando da entrada em vigor do Código Criminal do Império. (...) Passados cento e sessenta anos, em 1990, a Lei 8.072 (Lei dos Crimes Hediondos) contemplou a delação premiada em dois dispositivos (...)" (FERRO, Ana Luiza Almeida; PEREIRA, Flávio Cardoso; Gazzola, Gustavo dos Reis. Criminalidade Organizada - Comentários à Lei 12.850, de 02 de agosto de 2013. Curitiba: Juruá, 2014, p. 71-73).

4 Sobre o tema: SUXBERGER, A. H. G.; GOMES FILHO, Dermeval Faria. Funcionalização e expansão do direito penal: o Direito Penal negocial. Revista de Direito Internacional, Brasília, v. 13, n. 1, 2016, p. 377-39; VASCONCELLOS, Vinicius Gomes de. Barganha e Justiça Criminal Negocial. São Paulo: IBCCRIM, 2015. BRANDALISE, Rodrigo da Silva. Justiça Penal Negociada. Curitiba: Juruá, 2014; ROSA, Alexandre Morais da; LOPES JR., Aury. Com delação premiada e pena negociada, Direito Penal também é Lavado a Jato. Disponível em: <http://www.conjur.com.br/2015-jul-24/limite-penal-delacao-premiada-direito-penal-tambem-lavado-jato>. Acesso em: 28 ago. 2016.

5 Sobre a possibilidade de não oferecimento da denúncia (art. $4^{\circ}$, § $4^{\mathrm{o}}$, da Lei 12.850/13), por exemplo, a doutrina é bastante temerosa: "A previsão normativa em comento tem sido vista na doutrina como um abrandamento do princípio da obrigatoriedade, ou mesmo como uma exceção ao princípio da obrigatoriedade, porquanto, mesmo diante de crimes de ação penal pública e dispondo de elementos necessários para a propositura desta, preenchidos os requisitos legais, o Ministério Público 'poderá deixar de oferecer denúncia'. Há ainda quem defenda ter havido uma introdução do princípio da oportunidade da ação penal pública na sua forma regrada ou regulada" (MASSON, Cleber; MARÇAL, Vinícius. Crime organizado. São Paulo: Método, 2015. p. 118-119). 
O estudo reclama, assim, de um direcionamento mais preciso, sob pena de nada acrescentar ao atual cenário de discussões. O critério para delimitação temática consistiu numa indagação que já despertou intensos debates, mas ainda se encontra distante de qualquer tipo de consenso: é possível admitir que o acordo de colaboração premiada seja firmado no momento de maior vulnerabilidade do colaborador - a prisão?

Quando se decide investigar a voluntariedade dos acordos de colaboração premiada, não há como se esquivar da dura crítica referente à restrição da liberdade do colaborador. Esses dois institutos - prisão preventiva e colaboração premiada -, embora não possuam (ou não devam possuir) um vínculo natural de causa e efeito, veem-se intrinsecamente ligados na prática.

A discussão é reforçada pelo Projeto de Lei 4.372/16, que pretende alterar a Lei 12.850/13 e estabelecer como condição para a homologação judicial da colaboração premiada a circunstância de o acusado ou indiciado responder em liberdade à investigação ou ao processo instaurado em seu desfavor. A possibilidade de alteração da regulamentação jurídica do instituto impõe um estudo mais cuidadoso sobre a questão.

Daí a escolha do tema que se apresenta como título do presente trabalho - se não há como falar de colaboração premiada sem falar de prisão, o melhor a se fazer é enfrentar o problema. Como ponto de partida, observa-se que se trata de uma questão desprovida de estudos qualitativos que indiquem a relação existente entre imposição de custódia cautelar e a celebração de colaboração premiada. Além disso, a indagação não tem sido feita de forma ampla, mas tem se restringido em regra a um único caso $^{6}$ - a chamada Operação Lava

6 Sobre o conceito de "caso penal”, ler: COUTINHO, Jacinto N. Miranda. A Lide e o Conteúdo do Processo Penal. Curitiba: Juruá, 1989. p. 134ss; SILVEIRA, Marco Aurélio Nunes da. A ação processual penal entre política e constituição: outra teoria para o direito processual penal. E, ainda: "Por caso penal, entendese esse fenômeno que retrata a situação de incerteza, de dúvida ainda provisória, sobre a ocorrência do fato naturalístico descrito pelo autor e também sofre a qualificação jurídica desse fato, e que pode implicar na(sic) necessidade da aplicação de uma resposta penal ao réu que incidir no tipo penal, Segue-se, neste particular, a lição de Jacinto Nelson de Miranda Coutinho, para defender que o caso penal, portanto, é o conteúdo do processo penal” (CASARA, Rubens RR; MELCHIOR, Antonio Pedro. Teoria do Processo Penal Brasileiro. v. I. Rio de Janeiro: Lumen Juris, 2013. p. 290). 
$\mathrm{Jato}^{7}$, cuja peculiaridade de tramitar diretamente, por meio de alguns de seus processos, no Supremo Tribunal Federal trouxe impactos relevantíssimos no cenário político. A discussão, pois, sobre o instituto suplanta a preocupação estritamente jurídica e se transforma em tema do debate político nacional.

É importante situar o caso mencionado - Operação Lava-jato - como razão para explicitar o estudo do instituto da colaboração premiada e sua relação com a voluntariedade do desejado colaborador. Winfried Hassemer destaca que a moderna literatura de formação jurídico-penal muitas vezes complementa suas apresentações com casos. Estes se distinguem por aspectos que variam desde a extensão, a procedência, a proximidade com a realidade até a integridade das informações. O caso, destaca Hassemer, determina de modo vigoroso a formação no Direito Penal ${ }^{8}$ (e também no Direito Processual Penal, cuja aproximação é indissociável de seu conteúdo material).

O caso, contudo, presta-se somente como meio de demonstração. A advertência é relevante porque o caso não se encontra no mesmo nível do sistema, da teoria, da lei ou da atividade interpretativa no momento de compreensão do fenômeno jurídico. É dizer: não se pode confundir o caso com o instituto ou o fenômeno jurídico em estudo.

O caso, pois, é um fragmento da vida que, por fim, encontra o que a literatura jurídico-penal quer transmitir: a lei e seu manuseio. Não se pode confundir o caso com o instituto em si, tampouco limitar as soluções dadas ao caso como as soluções possíveis à abordagem do instituto jurídico.

7 A chamada "Operação Lava-jato" refere-se ao conjunto de investigações e ações penais sobre recursos desviados da Petrobrás com o envolvimento de empreiteiras. Os processos versam sobre crimes de corrupção, lavagem de dinheiro e outros. O nome "Lava-jato" remete ao uso de uma rede de postos de combustíveis e lava a jato de automóveis que ensejou o início das apurações. Dada a indicação de envolvimento de agentes públicos detentores de cargos com foro por prerrogativa de função, os processos distribuíram-se no Supremo Tribunal Federal e, em primeira instância, nas seções judiciárias da Justiça Federal em Curitiba, Rio de Janeiro e Brasília. Sobre os números da Operação, confira-se o site institucional do Ministério Público Federal: <http://lavajato.mpf.mp.br/>. Acesso em: 2 dez. 2016.

8 HASSEMER, W. Introdução aos fundamentos do Direito Penal, p. 36-37. 
Assim, é certo que grande parte das críticas, considerações e lições aqui tratadas sobre o problema do artigo se referem ao caso "Lavajato”. Por conseguinte, algumas advertências são necessárias sobre o modo de problematização que considera o caso (seja como visualização do problema, seja como leimotiv das manifestações dos juristas). A primeira delas refere-se ao fato de que o caso contém mais informações e estabelece mais questões que a apresentação sistemática ensejadora dos comentários sobre ele. A segunda, o caso é um ótimo meio de estudo independente, mas não pode situar unicamente ou restringir o problema jurídico ao que ocorre no caso eleito. Terceiro, o caso não descreve práticas profissionais, ele as documenta. A rotina profissional é difícil de ser compreendida, transmitida e, até mesmo, criticada. A prática da profissão jurídica é procedimento concreto acompanhado da teoria. A descrição, então, bem retocada do caso precisa ganhar forma e estar ao alcance daquele que o estuda. O caso, pois, "não pode afastar-se deste limite, mas ele pode torná-lo menor". ${ }^{\circ}$

Desse modo, veja-se que a abordagem da colaboração premiada pode, decerto, beber do caso "Operação Lava-jato”, mas não pode a ele se limitar e, mesmo dentro do caso, não pode confundir a atuação institucional dos diversos atores do sistema de justiça criminal com aquilo que ocorre no caso eleito ${ }^{10}$.

9 HASSEMER, W. Introdução, p. 45.

10 Dentro da proposta de diferenciação entre o caso penal e o instituto em si, Thiago Bottino faz interessante estudo sobre a Operação Lava-Jato, demonstrando os desvios ocorridos na prática, que não condizem com os contornos legais da colaboração premiada: "Contudo, a colaboração premiada, da forma como tem sido utilizada na conhecida 'Operação Lava Jato', a partir dos três acordos de colaboração premiada examinados acima, oferece benefícios muito maiores dos que aqueles previstos em lei, desequilibrando o sistema de dissuasão para cooperações falsas ou redundantes. É certo que a ampliação dos benefícios, ainda que dissociada do aumento dos custos em caso de afirmações inverídicas, não torna o mecanismo de cooperação inválido. No entanto, reforça a percepção de que, tal como na delação premiada, as declarações prestadas pelos acusados colaboradores não devem ser consideradas provas, mas somente meios de investigação" (BOTTINO, Thiago. Colaboração premiada e incentivos à cooperação no processo penal: uma análise crítica dos acordos firmados na "Operação Lava Jato”. Revista Brasileira de Ciências Criminais, São Paulo, v. 24, n. 122, p. 359-390, ago. 2016. p. 387). 
Pretende-se identificar os principais argumentos favoráveis e contrários à legitimidade do acordo firmado pelo colaborador preso e delinear o panorama jurídico da questão, para além do caso que muitas vezes enseja a manifestação geral sobre o tema. Note-se que a pretensão de alteração legislativa noticiada não impactará necessariamente nos processos em andamento, daí a preocupação de se pensar prospectivamente acerca dos problemas que tocam o instituto da colaboração premiada.

Ao final, propõe-se releitura sobre a relação entre prisão processual e colaboração premiada. Deve-se identificar a origem do problema, para somente então serem buscadas as soluções adequadas.

\section{Polêmicas e problematização}

O fato de a pessoa encontrar-se presa preventivamente por ordem da autoridade judiciária retira a legitimidade do acordo de colaboração premiada? Essa é a questão que tem dividido os especialistas.

Em palestra proferida no $7^{\circ}$ Congresso Brasileiro de Sociedades de Advogados, em São Paulo, o Ministro Marco Aurélio de Mello, do Supremo Tribunal Federal, afirmou que a colaboração premiada do réu preso seria um "ato de covardia"11. Segundo o Ministro:

Acima de tudo, a delação tem que ser um ato espontâneo. Não cabe prender uma pessoa para fragilizá-la para obter a delação. A colaboração, na busca da verdade real, deve ser espontânea, uma colaboração daquele que cometeu um crime e se arrependeu dele ${ }^{12}$.

Dessa sucinta declaração, extraem-se relevantes críticas que podem ser visualizadas nas seguintes perguntas: a prisão do réu retira a voluntariedade necessária para a colaboração premiada? Limites éticos estariam sendo rompidos com a combinação entre colaboração e prisão?

No meio acadêmico, a crítica acima apresentada encontra ecos. Durante ato em defesa da democracia na Faculdade de Filosofia, Letras

\footnotetext{
11 RODAS, Sérgio. Delação premiada é ato de covardia, afirma ministro do STF Marco Aurélio: coação ilegal. 16 ago. 2016. Consultor Jurídico. 
e Ciências Humanas (FFLCH), da Universidade de São Paulo (USP), chegou-se a afirmar que "prisão preventiva para obter a delação premiada é tortura". ${ }^{13}$ Aury Lopes Jr., em ocasião diversa, também associou a suposta prática com a tortura. Em suas palavras, seria uma "releitura do modelo medieval, em que se prendia para torturar, com a tortura se obtinha a confissão, e, posteriormente usava-se a confissão como a rainha das provas. " ${ }^{14}$ Diogo Malan menciona expressamente o uso da prisão temporária como estratégia de coação física e psicológica, "podendo se prestar ao fim da extorsão de confissão ou delação premiada do investigado, sob a ameaça - explícita ou velada - de a autoridade policial requerer a sobredita prorrogação de prazo". ${ }^{15}$

No plano internacional, os instrumentos da justiça penal negocial são comparados à tortura, no que se refere à intimidação provocada no investigado, ao fundamento de que ambos, ainda que em intensidades distintas, retiram o pleno discernimento, provocam dilemas no investigado, e potencializam o risco de falsas declarações, com a consequente condenação de inocentes ${ }^{16}$.

13 LIMA, Helder. Prisão preventiva para obter delação premiada é tortura, defende jurista: lava jato. 07 abr. 2016. Rede Brasil Atual.

CANÁRIO, Pedro. Professores criticam parecer sobre prisões preventivas na "lava jato": delação forçada. 18 nov. 2016. Consultor Jurídico.

15 MALAN, Diogo. Notas sobre a investigação e prova da criminalidade econômico-financeira organizada, p. 224.

16 Nesse sentido: "The tortured confession is, of course, markedly less reliable than the negotiated plea, because the degree of coercion is greater. An accused is more likely to bear false witness against himself in order to escape further hours on the rack than to avoid risking a longer prison term. But the resulting moral quandary is the same" (LANGBEIN, John H. Torture and Plea Bargaining, p. 15). Dervan e Edkins destacam que, embora as discussões sobre a plea bargaining sejam datadas do final do século XIX, sua origem remonta a muitos séculos antes e tem como referência o advento da própria confissão (guilty plea) no Direito, para tocar, então, mais se oito séculos no passado. E mesmo a confissão, segundo precedente inglês de 1783, não era admissível se entendida como uma confissão forçada. Em conclusão: "While plea bargaining as it exists today relies upon the use of incentives, common law prohibitions on such inducements persisted until well into the twentieth century" (DERVAN, Lucian E.; EDKINS, Vanessa. The Innocent Defendant's Dilemma, p. 7). 
No mesmo sentido foram as declarações de Leonardo Sica, presidente da Associação dos Advogados de São Paulo (AASP), que definiu o problema como um "pau de arara virtual":

Essa combinação entre prisão preventiva e delação premiada soa para nós como uma espécie de tortura soft é como um pau de arara virtual, as pessoas são presas preventivamente e só são soltas se confessarem. Isso é muito preocupante e não é necessário, existem outros métodos de investigação e de colheita de prova sem violar os direitos e garantias do cidadão. ${ }^{17}$

Soa exagerada a consideração de que a incorporação de instrumentos para enfrentamento de organizações criminosas, como é o caso da colaboração premiada, represente ruptura de todo o programa político-criminal brasileiro em face da Constituição. Se há ruptura, "essa se refere ao mundano do sistema de justiça criminal, cujo recorte etário, social e de gênero está a indicar as raízes de um sistema distante de um acesso igualitário ou, ao menos, não hierarquizado de modo apriorístico do bem imaterial chamado justiça". ${ }^{18}$

Outro questionamento importante é extraído dessas manifestações: a prisão preventiva do colaborador é sempre um ato de coação por parte do Estado?

Na visão de Lênio Streck, a questão envolve a presunção de inocência. A utilização da prisão como ferramenta de estímulo para a colaboração consistiria em verdadeira inversão do ônus da prova, incompatível com o sistema processual penal, que se funda na presunção de não culpabilidade. Nesse sentido, levanta intrigantes questionamentos: " $a$ polícia e o MP não conseguem provas sem delação? Querem inverter o ônus da prova? Caímos na república da responsabilidade objetiva-penal?". ${ }^{19}$

Ainda no tocante às garantias constitucionais do acusado, Pedro Estevam Serrano ressaltou a vedação de tratamento degradante, previs-

17 LOPES, Elizabeth. Prisão preventiva com delação premiada é pau de arara virtual, diz Sica. 01 mar. 2015. Estadão Política.

18 SUXBERGER, A. H. G. Colaboração premiada e a adoção da oportunidade no exercício da ação penal pública, p. 8.

19 CANÁRIO, Pedro. Professores criticam parecer sobre prisões preventivas na "lava jato": delação forçada. 18 nov. 2016. Consultor Jurídico. 
ta no art. $5^{\circ}$, inciso III, da CRFB $/ 88$. Afirmou que "a prisão preventiva tem sido usada para obter delações. Isso é absolutamente inconstitucional porque ofende um parágrafo do artigo $5^{\circ}$ da Constituição, que determina que não pode haver tratamento degradante". ${ }^{20}$

Não há como negar que essas reflexões despertam uma preocupação sobre a compatibilidade entre a colaboração premiada e as garantias constitucionais. Indaga-se, assim: a solução seria proibir a homologação do acordo de colaboração premiada do colaborador que se encontrava com a sua liberdade restringida?

Em contrapartida às críticas, muitos têm sustentado que a suposta conexão entre prisão e delação é falaciosa e representa estratégia dos investigados para nulificar os acordos celebrados. Deltan Dallagnol, Procurador da República que coordena a força-tarefa do Ministério Público Federal nas investigações e ações penais da chamada "Operação Lava Jato”, enfatizou que o fundamento das prisões preventivas é legítimo, pois teria por finalidade "proteger a sociedade de mais corrupção". ${ }^{21}$ Ressaltou, ainda, que a imposição de prisão processual "não estava presente em mais de $70 \%$ das colaborações, que foram feitas com réus soltos". ${ }^{22}$ Assim, denominou de mentirosas as afirmações que procuram associar colaboração premiada e prisão preventiva:

A única função de se repetir a mentira de que prisões são feitas como torturas é criar uma atmosfera de irregularidades e abrir espaço para que teses de nulidade ganhem corpo nos tribunais. A advocacia das nulidades, tão fértil no Brasil, tira o foco dos crimes de corrupção, tão extensos e intensos na violação de direitos fundamentais da população que caracterizam um verdadeiro atentado contra a humanidade, para colocar os holofotes em questões procedimentais. ${ }^{23}$

No mesmo sentido são as ponderações de Vladimir Aras:

20 Idem.

21 DELLAGNOL, Deltan. Lava Jato não usa prisões para obter colaboração de réus. 17 nov. 2015. UOL notícias Opinião.

22 Idem.

23 Idem. 
No caso Lavajato, até maio de 2015, foram formalizados 18 acordos de colaboração premiada, três deles no STF, um na Vara Federal do Rio de Janeiro e os demais na $13^{\text {a }}$ Vara Federal de Curitiba. Em apenas 4 dessas avenças os colaboradores estavam presos quando aceitaram negociar suas delações. Os demais estavam soltos e assim permaneceram. Entre os quatro que estavam cumprindo prisão preventiva durante a negociação, dois continuam presos preventivamente e os outros dois estão em prisão domiciliar. ${ }^{24}$

Tais afirmações levam a outras reflexões: a alegada relação entre prisão e colaboração é comprovada estatisticamente? O requisito da voluntariedade impõe que o colaborador esteja em liberdade?

A apropriação das críticas, muitas delas acertadas, dirigidas aos atos de vulneração da vontade do acusado para celebração de acordos processuais no direito norte-americano igualmente reclama ponderação. Isso porque, na modelagem normativa brasileira, há participação ativa do juiz na verificação da voluntariedade do acordo pelo acusado, como se observa da parte final do $\S 7 .^{\circ}$ do art. $4 .^{\circ}$ da Lei $12.850 / 2013$. Além disso, diferentemente da solução de um único caso, como ocorre na "plea" norte-americana, o acordo de colaboração submete o acusado à disposição da persecução penal, pois ele se prestará a indicar provas em todos os processos que versem sobre fatos imputáveis à organização criminosa.

Como se pode perceber a questão apresentada, além de estar em aberto, encontra-se muito distante de um caminho de consenso. Aliás, o dissenso não se dá apenas em relação à eventual conformidade entre os institutos da prisão e da colaboração premiada, mas até mesmo em relação ao modo como são considerados e representados na prática dos casos que fomentam a discussão entre operadores do Direito em geral.

\section{Projeto de Lei N. 4.372/2016}

O dissenso acima apresentado alcançou o cenário político por meio do Projeto de Lei n. 4.372/16, de autoria do Deputado Federal

24 ARAS, Vladimir. Sétima crítica: a prisão preventiva do colaborador é usada para extorquir acordos de colaboração premiada. 13 maio 2015. Blog do Vlad. 
Wadih Damous. Entre outros pontos, a proposição estabelece como condição para a homologação judicial da colaboração premiada a circunstância de o acusado ou indiciado responder em liberdade à investigação ou ao processo instaurado em seu desfavor.

Para tanto, o art. $3^{\circ}$ da Lei $12.850 / 13$ passaria a conter um terceiro parágrafo, com a seguinte redação:

Art. $3^{\circ}$

$\S 3^{\circ}$ No caso do inciso I, somente será considerada para fins de homologação judicial a colaboração premiada se o acusado ou indiciado estiver respondendo em liberdade ao processo ou investigação instaurados em seu desfavor.

$(\mathrm{NR})^{25}$

Na justificativa do Projeto ${ }^{26}$, enfatizou-se a ideia de que a prisão cautelar não deve ser utilizada como instrumento psicológico de pressão sobre o acusado ou indiciado, sob pena de se violar a dignidade da pessoa humana. Segundo o autor da proposição, o objetivo é evitar que prisões sejam decretadas sem fundamentação idônea e com finalidades extrínsecas ao processo ou inquérito. Merece destaque a seguinte passagem da justificativa do projeto de lei:

Assim, a colaboração premiada pressupõe para sua validade ausência de coação, impondo uma clara e inafastável liberdade do colaborador para querer contribuir com a justiça. A voluntariedade exigida pela legislação desde 1999 e assimilada pelo legislador de 2013 é incompatível com a situação de quem se encontra com a liberdade restringida. É uma contradição em termos.

25 BRASIL. Câmara dos Deputados. Projeto de Lei 4.372/2016. Disponível em: <http://www.camara.gov.br/proposicoesWeb/fichadetramitacao?idProposicao=2077165 > Acesso em 7 set. 2016. BRASIL. Justificação do Projeto de Lei 4.372/2016. Disponível em: <http:// www.camara.gov.br/proposicoesWeb/prop_mostrarintegra;jsessioni$\mathrm{d}=9 \mathrm{~B} 188 \mathrm{C} 8 \mathrm{C} 00057 \mathrm{~F} 8494 \mathrm{AB} 5 \mathrm{~A} 8 \mathrm{BDF} 3 \mathrm{BB} 83 \mathrm{~A}$.proposicoesWeb2? codteor $=1433188 \&$ filename $=$ PL+4372/2016>. Acesso em: 7 set. 2016. 
O Projeto, ao ser apresentado e discutido na Comissão de Segurança Pública e Combate ao Crime Organizado da Câmara dos Deputados, obteve parecer desfavorável à sua admissibilidade e tramitação. Na visão da referida Comissão, a premissa do projeto está equivocada, uma vez que "não existe nenhuma correlação, nenhum liame entre o instituto da delação, que tem natureza penal e o da prisão, que tem caráter processual". ${ }^{27}$

O parecer ressalta, ainda, a diferença entre liberdade psíquica e liberdade de locomoção, nos seguintes termos:

Com efeito, a voluntariedade - necessária para a validade da colaboração premiada, nos termos do art. $4^{\circ}$ da Lei $n^{\circ} 12.850$, de 2013 - diz respeito à liberdade psíquica do colaborador, que não pressupõe a sua liberdade de locomoção. Aliás, a prisão cautelar não tem qualquer relação com a colaboração premiada, seja porque não pode ser imposta como forma de pressionar uma colaboração, seja porque não pode ser revogada simplesmente porque houve a colaboração ${ }^{28}$.

No momento, o projeto se encontra na Comissão de Constituição e Justiça e de Cidadania (CCJC).$^{29}$ Como se vê, embora a tramitação do projeto ainda não esteja concluída, os argumentos mais relevantes sobre a questão, favoráveis e contrários, já foram levantados.

\section{A RELAÇÃo ENTRE PRISÃo PREVENTIVA E COLABORAÇÃo - INVENÇÃo OU REALIDADE?}

A intensidade das discussões sobre o tema é evidente. Não se trata de mera divergência, mas de verdadeira polêmica, com argumentos consistentes nos dois sentidos. É esse o atual cenário do problema.

27 BRASIL. Comissão de segurança pública e combate ao crime organizado. Parecer pela rejeição do Projeto de Lei n. 4.372, de 2016. Relator: Delegado Edson Moreira. Disponível em: <http://www.camara.gov.br/proposicoesWeb/prop_mostrarintegra;jsessionid=9B188C8C00057F8494AB5A8BDF3BB83A.proposicoesWeb2 ? codteor $=1485107 \&$ filename $=$ Parecer - CSPCCO-22-08-2016>. Acesso em: 7 set. 2016. Idem.

Até o dia 20 de dezembro de 2016. 
Importa, pois, realizar uma análise jurídica das principais ideias apresentadas no debate, a fim de problematizar a questão do ponto de vista técnico. Não se pretende, com isso, pacificar a questão, tampouco exaurir o tema, mas apenas analisar juridicamente a relação entre prisão preventiva e colaboração premiada, identificar a origem da alegada incompatibilidade entre os institutos, e, assim, contribuir para que sejam encontradas soluções compatíveis com o problema existente.

\subsection{Voluntariedade}

$\mathrm{O}$ art. $4^{\circ}$, caput, da Lei $12.850 / 2013$ é expresso ao eleger a voluntariedade como pressuposto para a homologação da colaboração premiada: "O juiz poderá, a requerimento das partes, conceder o perdão judicial, reduzir em até $2 / 3$ (dois terços) a pena privativa de liberdade ou substituí-la por restritiva de direitos daquele que tenha colaborado efetiva e voluntariamente com a investigação e com o processo criminal".

Questiona-se: a condição de preso é compatível com a voluntariedade exigida pela lei?

Para muitos, como já noticiado, a resposta é negativa. ${ }^{30}$ Gustavo Badaró sustenta que a incompatibilidade entre voluntariedade e prisão se inicia com a semântica. O autor trabalha as duas expressões como antônimas, inconciliáveis entre si:

Voluntário advém do latim voluntarius,a,um, significando "que age por vontade própria”. Um agir voluntário é, portanto, um ato que se pode optar por praticar ou não. É atributo de quem age apenas segundo sua vontade. Ou, definindo negativamente: voluntário é o agir que não é forçado. Por outro lado, que prisão é coação, é o que diz a própria Constituição, assegurando o habeas

30 BADARÓ, Gustavo. Quem está preso pode delatar? 23 jun. 2015. JOTA; JARDIM, Afrânio Silva, entrevista; MENDES, Soraia da Rosa; BARBOSA, Kássia Cristina de Sousa. Anotações sobre o Requisito da Voluntariedade e o Papel do/a Juiz/a em acordos de colaboração premiada envolvendo investigados/as e/ou réus/rés presos/as provisoriamente. In: A delação/colaboração premiada em perspectiva. Brasília: IDP, 2016. p. 72-89. 
corpus para quem sofre "coação em sua liberdade de locomoção", de modo ilegal. ${ }^{31}$

Nessa mesma linha de pensamento, tantos outros ${ }^{32}$ procuram demonstrar que a prisão configura o momento de maior vulnerabilidade do investigado ou acusado, o que lhe retira a possibilidade de escolha. A prisão é descrita como o momento mais aterrorizante para o investigado ou acusado, de modo que não há como conceber que ele exerça a sua vontade de forma autônoma. Seu único objetivo será retomar o quanto antes a sua liberdade. Para tanto, fará o que for necessário, inclusive, assumir o papel de colaborador. ${ }^{33}$

31 BADARÓ, Gustavo. Quem está preso pode delatar? 23 jun. 2015. JOTA.

32 É o caso de Luiz Antônio Borri, que, ao responder sobre a compatibilidade entre o requisito da voluntariedade e a prisão do colaborador, afirma: "A pergunta formulada deve ser respondida em sentido negativo. Justifica-se esta perspectiva com base na interpretação conferida à Lei 12.850/2013, particularmente à necessária voluntariedade do ato pelo acusado delator, assim como para impor limite intransponível ao Estado na persecução penal, caracterizando-se a ilicitude da colaboração premiada firmada nas hipóteses de acusados/investigados presos e de todos os elementos probatórios dela oriundos, nos termos do art. 157, § 1. ${ }^{\circ}$, do Código de Processo Penal” (BORRI, Luiz Antonio. Delação premiada do investigado/acusado preso cautelarmente: quando o Estado se transfigura em criminoso para extorquir a prova do investigado. Boletim IBCCRIM, São Paulo, ano 24, n. 285, p. 6-8, ago. 2016). Ademais, como visto, foram essas as declarações do Ministro do Supremo Tribunal Federal Marco Aurélio de Mello, Lenio Streck, Aury Lopes Jr., Leonardo Sica, Pedro Estevam. Disponível em: <http://www.conjur.com.br/2016-ago-12/ delacao-premiada-ato-covardia-afirma-ministro-marco-aurelio $>$. Acesso em: 24 ago. 2016; <http://www.redebrasilatual.com.br/politica/2016/04/prisao-preventiva-para-pressionar-delacao-premiada-e-uma-forma-de-torturadefende-jurista-6505.html>. Acesso em: 24 ago. 2016; <http://www.conjur. com.br/2014-nov-28/professores-criticam-parecer-prisao-preventiva-lavajato>. Acesso em 24 ago. 2016; <http://politica.estadao.com.br/noticias/ geral,prisao-preventiva-com-delacao-premiada-e-pau-de-arara-virtual-dizsica,1642213>. Acesso em: 26 ago. 2016.

33 Nesse sentido: "O que mais pode ser aterrorizante, intimidador, opressivo para um investigado/a ou acusado/a em um processo penal (de regra espetacularizado) do que a possibilidade de ver a sua liberdade cerceada por mais um dia, um mês (ou vários dias ou meses), caso não se transforme em um/a delator/a?" (MENDES, Soraia da Rosa; BARBOSA, Kássia Cristina de Sousa. Anotações sobre o Requisito da Voluntariedade e o Papel do/a Juiz/a em acordos de colaboração premiada envolvendo investigados/as e/ou réus/rés 
$\mathrm{O}$ argumento central pode ser sintetizado na ideia de que, sem liberdade plena, não existe voluntariedade. A restrição da liberdade física suprime a liberdade de opção. A prisão é um ato de violência, de coação, que obriga o acusado a colaborar e, assim, viola a diretriz estabelecida pelo art. $4^{\circ}$, caput, da Lei $12.850 / 2013$.

À primeira vista, tal argumento parece insuperável. Qualquer um é capaz de imaginar que, estando preso, faria o que fosse preciso para recuperar a liberdade. A liberdade de locomoção é inerente à essência humana e tem forte influência na liberdade de escolha. Todavia, é possível (e necessário) analisar a questão sob outra perspectiva, que também se inicia com o aspecto semântico - a diferença entre "voluntariedade" de "espontaneidade":

A delação premiada deve ser produto da livre manifestação pessoal do delator, sem sofrer qualquer tipo de pressão física, moral, ou mental, representando, em outras palavras, intenção ou desejo de abandonar o empreendimento criminoso, sendo indiferentes as razões que o levam a essa decisão. Não é necessário que seja espontânea, sendo suficiente que seja voluntária: há espontaneidade quando a ideia inicial parte do próprio sujeito; há voluntariedade, por sua vez, quando a decisão não é objeto de coação moral ou física, mesmo que a ideia inicial tenha partido de outrem, como da autoridade, por exemplo, ou mesmo resultado de pedido da própria vítima. O móvel, enfim, da decisão do delator - vingança, arrependimento, inveja ou ódio - é irrelevante para efeito de fundamentar a delação premiada. ${ }^{34}$

Assim, a voluntariedade, tal como exigida pela lei, não consiste em uma ideia que surge, em primeiro lugar, na mente do acusado ou investigado. $\mathrm{O}$ acordo pode ser sugerido pelas autoridades responsáveis pela investigação, desde que não haja coação. Esse é o ponto que tem sido frequentemente confundido nas discussões sobre o tema: a lei não exige espontaneidade.

presos/as provisoriamente. In: A delação/colaboração premiada em perspectiva. Brasília: IDP, 2016. p. 85).

34 BUSATO, Paulo César; BITENCOURT, Cezar Roberto. Comentários à Lei de Organização Criminosa - Lei 12.850/2013. São Paulo: Saraiva, 2014. p 119. 
A grande questão para a preservação da voluntariedade, portanto, não é identificar quando houve algum tipo de influência por parte dos agentes estatais, mas se e quando houve coação, isto é, cumpre indagar o significado da coação. Para responder a essa questão, alguns autores ${ }^{35}$ propõem uma analogia entre a colaboração premiada e o negócio jurídico regulado pelo Código Civil, tendo em vista que se está diante de um acordo entre acusação e defesa.

Para tanto, adota-se como referência o conceito trazido pelo artigo 151 do CC/02, que define coação como o ato que incute "ao paciente fundado temor de dano iminente e considerável à sua pessoa, à sua família, ou aos seus bens". Nesse sentido, seria possível argumentar, em primeira percepção, que a sensação provocada pela prisão - tão temida pelo réu - enquadra-se no conceito legal de coação, o que poderia ensejar a anulação dos acordos de colaboração premiada celebrados por co-

35 Nesse sentido: "Percebe-se, assim, que a colaboração premiada tem a configuração jurídica de um contrato. Trata-se, de fato, de um acordo onde o Ministério Público e o acusado discutem e negociam livremente as cláusulas de um ajuste que, se fielmente cumprido, acarretará, ao final, relevantes benefícios para ambas as partes. A Lei n. ${ }^{\circ}$ 12.850/2013, inclusive, em diversas passagens de seu texto ressalta a natureza contratual da colaboração premiada, quando se utiliza, por exemplo, dos termos "negociações realizadas entre as partes para a formalização do acordo de colaboração" (art. $4^{\circ}, \S 6^{\circ}$ ), "homologado o acordo" (art. $\left.4^{\circ}, \S 9^{\circ}\right)$, "termos do acordo homologado e sua eficácia (art. $4^{\circ}, \S 11$ ), "em todos os atos de negociação" (art. $\left.4^{\circ}, 15\right)$ e, principalmente, que o "termo de acordo da colaboração premiada deverá ser feito por escrito e conter : I - o relato da colaboração e seus possíveis resultados; II - as condições da proposta do Ministério Público ou do delegado de polícia; III - a declaração de aceitação do colaborador e de seu defensor; IV - as assinaturas do representante do Ministério Público ou do delegado de polícia, do colaborador e de seu defensor; $\mathrm{V}$ - a especificação das medidas de proteção ao colaborador e à sua família, quando necessário" (art. 6º)". Disponível em: <http://jota.uol.com.br/rodrigo-de-grandis-prisao-nao-invalida-a-delacao -premiada>. Acesso em 11 set. 2016. E ainda: "Se nada for feito, sem a genialidade de Sobral Pinto, no futuro nos restará postular a anulação dos contratos de delações premiadas de investigados presos, invocando como fundamento o Código Civil, que em seu artigo 171, inciso II, ao tratar da invalidade dos negócios jurídicos, considera anulável negócios jurídicos celebrados mediante ‘coação’ ou em ‘estado e perigo'!”. Disponível em: <http://jota.uol.com.br/ quem-esta-preso-pode-delatar>. Acesso em: 11 set. 2016. 
laborador preso, a teor do art. 171 , II do CC/02. ${ }^{36}$ Contudo, tal conclusão só poderia ser admitida a partir de uma análise isolada do art. 151, que, além de não esgotar o conceito de coação, pode induzir o intérprete ao equívoco de conceber o conceito de forma ampla.

A leitura sistemática do Código Civil conduz, ao contrário, a uma concepção restritiva de coação. O art. 153 do Código Civil esclarece que "não se considera coação a ameaça do exercício normal de um direito". Em outras palavras, somente há coação se houver ilegalidade. Rodrigo de Grandis bem recorda a famosa expressão de Orosimbo Nonato: "Não há direito contra direito". ${ }^{37}$

Assim, a prisão preventiva não pode ser tratada, de forma genérica, como um ato de coação, se ela foi decretada pela autoridade competente, em observância aos requisitos legais. Como visto, a coação possui um sentido técnico, que não pode ser ignorado.

Poder-se-ia argumentar, ainda, que não há equilíbrio entre as partes envolvidas no acordo, para que se aplique a lógica civilista de coação - de um lado, encontra-se toda a força do aparato estatal e, do outro, toda a vulnerabilidade do acusado preso.

Sobre esse ponto, importa recordar que a Lei 12850/13 regulou o instituto da colaboração premiada de forma mais detalhada, de modo a tutelar o colaborador e amenizar a sua posição de vulnerabilidade. Cleber Masson e Vinicius Marçal assim sintetizam a evolução legislativa do instituto:

A evolução legislativa sobre o instituto denota o quanto veio sendo lapidada a colaboração premiada entre nós. Em sua gênese,

36 Art. 171. Além dos casos expressamente declarados na lei, é anulável o negócio jurídico: I - por incapacidade relativa do agente; II - por vício resultante de erro, dolo, coação, estado de perigo, lesão ou fraude contra credores.

37 “'Não há direito contra direito', já afirmou Orosimbo Nonato em famosa obra sobre a coação como defeito do ato jurídico. Desse modo, é possível deduzir que, por traduzir um ato emitido em conformidade com o direito, ou seja, uma vez decretada por um juiz quando presentes os fundamentos legais, o fato de o agente encontrar-se preso temporária ou preventivamente por si só não invalida o acordo de colaboração premiada”. Disponível em: <http://jota. uol.com.br/rodrigo-de-grandis-prisao-nao-invalida-a-delacao-premiada>. Acesso em: 12 set. 2016. 
não se previa a forma como se efetivaria na práxis a "delação"; não havia regras visando à proteção do colaborador; poucos eram os prêmios legais. Esse estado de coisas fez com que Damásio de Jesus chegasse a rotular o instituto como "fracassado".

Por outro lado, a Lei 12.850/2013 alterou sensivelmente esse quadro. Surgiram regras claras para a celebração do acordo; o magistrado foi afastado da negociação; exigiu-se requerimento e homologação judicial; foram previstos direitos ao colaborador, tipificou-se como crime a revelação indevida de sua identidade; surgiram novos prêmios (v.g., "acordo de não denunciar ou "acordo de imunidade"). ${ }^{38}$

A lei tornou claro que a presença do advogado do colaborador é indispensável em todos os atos (art. $4, \S 15^{39}$ ). Assim, há, ao menos em tese, a fiscalização imediata de todos os atos praticados até a homologação do acordo de colaboração. Qualquer ameaça indevida pode ser imediatamente constatada pelo advogado, que poderá adotar as medidas cabíveis para afastá-la. Em verdade, contra eventual possibilidade de uso arbitrário do aparato estatal que promove a persecução penal o remédio mais robusto é mesmo a assistência jurídica ao investigado ou acusado. É dizer: a manifestação livre do colaborador é assegurada pelo pleno conhecimento da situação em que se encontra e pela ampla gama de instrumentos colocados em seu favor por meio justamente da atuação livre do advogado. Este, é bom lembrar, exercita múnus público quando no exercício de função que, constitucionalmente, mostra-se essencial à Justiça (nos estritos termos do art. 133 da CRFB/88).

A lei previu, ainda, uma audiência especial, em que o juiz - que não participa das negociações ${ }^{40}$ - poderá sigilosamente, ouvir o colabora-

38 MASSON, Cleber; MARÇAL, Vinícius. Crime organizado. São Paulo: Método, 2015. p. 96-97.

39 § 15. Em todos os atos de negociação, confirmação e execução da colaboração, o colaborador deverá estar assistido por defensor.

${ }^{40}$ Art. $4^{\circ}, \S 6^{\circ}$. O juiz não participará das negociações realizadas entre as partes para a formalização do acordo de colaboração, que ocorrerá entre o delegado de polícia, o investigado e o defensor, com a manifestação do Ministério Público, ou, conforme o caso, entre o Ministério Público e o investigado ou acusado e seu defensor. 
dor, na presença de seu defensor (art. $4^{\mathrm{o}}, \S 77^{\mathrm{ou1}}$ ), como forma de aferir a regularidade, legalidade e voluntariedade do acordo. A ideia é permitir ao colaborador que exponha ao juiz os reais motivos que o levaram a celebrar o acordo. Cleber Masson e Vinícius Marçal chegam a sustentar que tal audiência poderia se dar sem a presença do Ministério Público, justamente para assegurar que a manifestação de vontade do pretenso colaborador se desse livre de qualquer ingerência ou sem a inibição causada pela presença do membro do Ministério Público no ato processual. ${ }^{42}$

Essa alegação de ausência do membro do Ministério Público, porém, não parece guardar boa interpretação. Em verdade, ela traz à memória preceito antigo do Código de Processo Penal, que em seu artigo 520, autorizava o Juiz a proceder à oitiva das partes sem a presença de seus patronos. A justificativa consistiria na possibilidade de o Juiz, sem o ânimo dos patronos, obter das partes possível conciliação que frustraria a ação penal privada por crime contra a honra. A justificativa de Espínola Filho, em consagrada obra de comentários ao Código de Processo Penal da década de 1950, é tão marcada pelo patriarcalismo e pela fetichismo sobre a figura judicial que merece a transcrição literal:

A providência preliminar tem um aspecto singelo e eminentemente antiformalista, em que o juiz age com o tato e a prudência, com que os bons varões buscam implantar o entendimento entre as pessoas da sua família, ou das suas relações, quando se apresentam desavindas, muita vez por simples malentendidos. Bem andou a lei, eliminando os termos, a solenidade, a intervenção de advogados, para, apenas, da adolhida a um conciliábulo sem forma especial, em que o juiz procede como um conselheiro amigo, zeloso pela paz e pela harmonia na sociedade, onde exerce autoridade. ${ }^{43}$

$41 \S 7^{\circ}$ Realizado o acordo na forma do $\S 6^{\circ}$, o respectivo termo, acompanhado das declarações do colaborador e de cópia da investigação, será remetido ao juiz para homologação, o qual deverá verificar sua regularidade, legalidade e voluntariedade, podendo para este fim, sigilosamente, ouvir o colaborador, na presença de seu defensor.

42 MASSON, Cleber; MARÇAL, Vinícius. Crime organizado. São Paulo: Método, 2015. p.133.

43 ESPÍNOLA FILHO, E. Código de Processo Penal brasileiro anotado. 4. ed. Vol. V, p. 182. 
O fetichismo aqui parece se repetir, na esperança de que o colaborador só possa manifestar-se livremente na ausência do membro do Ministério Público ou mesmo que o juiz possa manifestar postura diversa daquela que teria na presença do membro do Ministério Público. O repúdio a atos que imponham segredos às partes, máxime quando o que se apura é justamente a liberdade na vontade de realizar o acordo, afasta a leitura que veicula restrição não manifestada expressamente no texto legal.

Não fosse o bastante, a lei estabeleceu, que, sempre que possível, o registro dos atos de colaboração será feito pelos meios ou recursos de gravação magnética, estenotipia, digital ou técnica similar, inclusive audiovisual, com o objetivo de obter maior fidelidade das informações (art. $4 .^{\circ}$, $\S 13)$. Além disso, o art 5. ${ }^{044}$ inovou ao estabelecer um rol de direitos, denominado por alguns de estatuto protetivo ${ }^{45}$, que tutela não apenas a intimidade, mas a incolumidade física do colaborador.

Como se vê, há uma série de medidas trazidas pela lei que permitem maior controle da legalidade da negociação e amenizam a situação de fragilidade do colaborador. Assim, ao menos em teoria, existem mecanismos que asseguram um maior equilíbrio no acordo entre acusação e defesa.

De todo modo, ainda que se afaste a possibilidade de analogia com o Direito Civil, existem outros fundamentos que permitem alcançar a mesma conclusão.

No Direito Penal, o conceito de coação pode ser extraído dos tipos penais contra a liberdade pessoal, notadamente os crimes de constrangimento ilegal e ameaça, previstos nos arts. 146 e 147 do Código

44 Art. $5^{\circ}$ São direitos do colaborador: I - usufruir das medidas de proteção previstas na legislação específica; II - ter nome, qualificação, imagem e demais informações pessoais preservados; III - ser conduzido, em juízo, separadamente dos demais coautores e partícipes; IV - participar das audiências sem contato visual com os outros acusados; V - não ter sua identidade revelada pelos meios de comunicação, nem ser fotografado ou filmado, sem sua prévia autorização por escrito; VI - cumprir pena em estabelecimento penal diverso dos demais corréus ou condenados.

45 MASSON, Cleber; MARÇAL, Vinícius. Crime organizado. São Paulo: Método, 2015., p.143. 
Penal $^{46}$. Novamente, faz-se presente a ideia de que a coação somente ocorre quando se age contra legem. O crime de constrangimento ilegal somente se configura se a vítima for constrangida "a não fazer o que a lei permite, ou a fazer o que ela não manda”. Por sua vez, a ameaça sempre deve ter por objeto um "mal injusto".

Importa analisar, ainda, os contornos dados à coação no âmbito do direito comparado, uma vez que o plea bargaining do direito norte -americano também elegeu a voluntariedade como pressuposto para a realização do acordo ${ }^{47}$. Anote-se que, no direito norte-americano, a legal colaboration, figura aproximada à colaboração premiada, aproveita-se da ampla e consolidada produção doutrinária e jurisprudencial elaborada sobre os acordos processuais de negociação da própria culpa do acusado (plea bargaining).

Segundo a orientação da Suprema Corte norte-americana, a acusação tem liberdade para tentar convencer o réu a colaborar, sob as mais diversas técnicas de persuasão, desde que elas possuam suporte legal. Assim, a proposta da colaboração, não apenas pode partir da acusação, como pode vir acompanhada de outras ponderações que reforcem a necessidade do acordo, como o risco de condenações a penas elevadas, desde que tais colocações encontrem correspondência na lei. ${ }^{48}$

46 Constrangimento ilegal. Art. 146 - Constranger alguém, mediante violência ou grave ameaça, ou depois de lhe haver reduzido, por qualquer outro meio, a capacidade de resistência, a não fazer o que a lei permite, ou a fazer o que ela não manda: Pena - detenção, de três meses a um ano, ou multa. Ameaça. Art. 147 - Ameaçar alguém, por palavra, escrito ou gesto, ou qualquer outro meio simbólico, de causar-lhe mal injusto e grave: Pena - detenção, de um a seis meses, ou multa.

47 Nesse sentido: "o procedimento alusivo ao plea bargaining é disciplinado pela Regra de Procedimento Criminal Federal $n^{\circ} 11$ - Federal Rules of Criminal Procedure, Rule 11 - Pleas. (...) A Regra Federal no 11, (b), (2) preconiza que o Juízo apenas aceita a declaração de culpa ou de não contestação após certificar a voluntariedade” (SANTOS, Marcos Paulo Dutra. Colaboração (delação) premiada. Salvador: JusPodivm, 2016. p. 33-36).

48 Nesse sentido, Marcos Paulo Dutra Santos cita diferentes precedentes da Suprema Corte norte americana e conclui: "A jurisprudência dos Tribunais, inclusive a da Suprema Corte, tolera que a declaração de culpa ou de nolo contendere seja obtida mediante coerção psicológica da acusação sobre o réu, desde que pautada em bases legais. Encara-se o plea bargaining como uma estratégia, em que se permite à acusação valer-se de todas as "armas" dis- 
Verifica-se, assim, que a Suprema Corte norte-americana também tem conferido interpretação restritiva à ideia de coação, ao entender que o requisito da voluntariedade somente é violado quando a acusação age fora da legalidade.

Todos esses argumentos corroboram a ideia de que a voluntariedade somente é afastada quando há coação, a qual pressupõe a existência de ilegalidade. Consequentemente, somente há incompatibilidade entre o requisito da voluntariedade e a restrição da liberdade do colaborador se a prisão for ilegal.

Nos próximos tópicos, será reforçado o ponto que ora se consolida: o problema não reside nos institutos em si, mas no abuso ou no mau uso destes. A modelagem normativa da colaboração premiada não permite que a prisão preventiva seja utilizada com instrumento de pressão. A incompatibilidade entre prisão e colaboração, se existente, não é jurídica, mas prática ${ }^{49}$.

\subsection{Os REQUISITOS DA PRISÃO PREVENTIVA}

Se a coação pressupõe a ilegalidade da prisão preventiva, é importante analisar seus requisitos e identificar qual tipo de fundamentação pode ser admitida. Será apresentado, sinteticamente, o significado de cada uma das expressões contidas no art. 312 do CPP, como forma de demonstrar que, se a prisão é utilizada como estímulo para colaboração premiada, isso é feito de forma velada, uma vez que os requisitos da preventiva, ao menos em tese, não se compatibilizam com esse tipo de conduta.

Eis o teor do art. 312 do CPP:

poníveis, dentro da legalidade, para persuadir o acusado a firmar o negócio jurídico processual” (SANTOS, Marcos Paulo Dutra. Colaboração (delação) premiada, p. 36-40).

49 Divergimos, assim, do entendimento de parcela da doutrina, que enxerga a coação como algo inerente à existência de acordos no processo penal, isto é, à Justiça Criminal Negocial. Merece destaque, como referência de aprofundado estudo sobre o tema, VASCONCELLOS, Vinicius Gomes de. Barganha e Justiça Criminal Negocial. São Paulo: IBCCRIM, 2015. No plano internacional: ALSCHULER, Albert W. The changing plea bargaining debate. California Law Review, n. 69, p. 652-730, 1981. 
Art. 312. A prisão preventiva poderá ser decretada como garantia da ordem pública, da ordem econômica, por conveniência da instrução criminal, ou para assegurar a aplicação da lei penal, quando houver prova da existência do crime e indício suficiente de autoria. (Redação dada pela Lei ${ }^{\circ} 12.403$, de 2011).

A partir de uma leitura superficial do dispositivo, poder-se-ia imaginar que a "conveniência da instrução criminal" autorizaria a utilização da prisão como instrumento para se provocar a colaboração do acusado, uma vez que facilitaria a comprovação dos crimes em apuração. Todavia, não é esse o significado técnico da expressão. O fundamento da "conveniência da instrução criminal" deve ser invocado quando o réu estiver intimidando ou aliciando testemunhas ou peritos, suprimindo ou alterando provas ou documentos, ou turbando, de qualquer forma, a apuração dos fatos, como forma de garantir o bom andamento da instrução criminal. ${ }^{50}$

A conveniência da instrução criminal não deve ser analisada, assim, sob a perspectiva da acusação (de encontrar o caminho mais "conveniente" de obtenção de provas). O seu objeto de análise é o comportamento do réu e o risco concreto que ele oferece à instrução processual.

Nem mesmo a garantia da ordem pública poderia justificar a utilização da prisão como estímulo para a colaboração. Em que pese a subjetividade e amplitude da ideia de ordem pública, prevalece, na doutrina ${ }^{51}$

50 LIMA, Renato Brasileiro de. Código de Processo Penal Comentado. Salvador: Juspodvim, 2016. p. 867.

51 Nesse sentido: "para uma segunda corrente, de caráter restritivo, que empresta natureza cautelar à prisão preventiva decretada com base na garantia da ordem pública, entende-se garantia da ordem pública como o risco considerável de reiteração de ações delituosas por parte do acusado, caso permaneça em liberdade, seja porque se trata de pessoa propensa à prática delituosa, seja porque, se solto, teria os mesmos estímulos relacionados com o delito cometido, inclusive pela possibilidade de voltar ao convívio com os parceiros do crime. Acertadamente, essa corrente, que é a majoritária, sustenta que a prisão preventiva poderá ser decretada com o objetivo de resguardar a sociedade da reiteração de crimes, em virtude da periculosidade do agente" (LIMA, Renato Brasileiro de. Código de Processo Penal Comentado. Salvador: Juspodvim, 2016. p. 861). 
e na jurisprudência ${ }^{52}$, que ela está ligada à periculosidade do sujeito, à gravidade concreta do delito praticado e, especialmente, ao risco de reiteração delitiva.

A necessidade de garantia da ordem pública é identificada a partir dos fatos já ocorridos que, por sua gravidade concreta ou por sua prática reiterada, justificam a custódia cautelar do agente. A pretendida colaboração do acusado não se enquadra no conceito jurídico de ordem pública. O mesmo raciocínio é aplicável à garantia da ordem econômica, espécie do gênero ordem pública, que exige a demonstração concreta do risco que o investigado ou acusado representa para a situação econômica de instituições financeiras ou do próprio ente estatal.

Por fim, a garantia de aplicação da lei penal relaciona-se ao risco concreto de evasão do custodiado ${ }^{53}$. A preocupação, nesse caso, é com a concretização do poder de punir do Estado e não com a construção do acervo probatório.

Como se vê, teoricamente, não há - nem deve haver - relação de causa e efeito entre prisão e colaboração. Se a prisão preventiva é decretada unicamente com o intuito de provocar a colaboração do acusado, ela é ilegal, pois a sua finalidade foi destorcida e manipulada de forma indevida. Nessa hipótese, há vulneração do requisito da voluntariedade, em virtude da ocorrência de coação do acusado, o que deve ensejar a nulidade do acordo e, consequentemente, dos elementos dele derivados.

Em outras palavras, a prisão preventiva não pode ser utilizada como instrumento de obtenção de provas, pois essa não é a sua finalidade. A prisão, como toda e qualquer medida cautelar não se relaciona com a construção do mérito da causa, mas sim, com a garantia do pro-

52 Vide, por exemplo: RHC 72.159/MG, Rel. Ministro Ribeiro Dantas, quinta turma, julgado em 15/12/2016, DJe 01/02/2017)

53 Nesse sentido: "Recordemos que é absolutamente inconcebível qualquer hipótese de presunção de fuga, até porque substancialmente inconstitucional frente à Presunção de Inocência. Toda decisão determinando a prisão do sujeito passivo deve estar calcada em um fundado temor, jamais fruto de ilações. Deve-se apresentar um fato claro, determinado, que justifique o receio de evasão do réu" (LOPES JR., Aury. Direito Processual Penal. 10 ed. São Paulo: Saraiva, 2013, p. 858). 
cesso e da persecução penal. Caso isso não seja respeitado, concretizase a coação por parte do aparato estatal e, assim, a violação ao requisito da voluntariedade.

\subsection{ETICIDADE}

Argumenta-se que o Estado estaria se curvando ao nível dos criminosos e se utilizando de tortura e chantagem para obter as informações desejadas. Sustenta-se que a acusação teria encontrado o caminho mais fácil: coagir o réu a colaborar e fornecer todos os elementos necessários para o êxito da persecução penal ${ }^{54}$.

Questiona-se, assim, se a ética teria sido esquecida no combate às grandes organizações criminosas. São colocadas em confronto a eticidade e a eficiência da persecução penal. Vem à tona o eterno dilema: os fins justificam os meios? A conclusão dessa reflexão é irretocável: se o combate à corrupção é extremamente necessário, é, também, essencial que esse combate seja feito dentro da legalidade, sob pena de apenas se substituir um problema pelo outro ${ }^{55}$. Todavia, a premissa é discutível: é possível presumir que o Estado está agindo de forma ilegal?

54 Novamente, recorda-se o teor das declarações do Ministro do Supremo Tribunal Federal Marco Aurélio de Mello, Lenio Streck, Aury Lopes Jr., Leonardo Sica, Pedro Estevam. Disponível em: <http://www.conjur.com. br/2016-ago-12/delacao-premiada-ato-covardia-afirma-ministro-marco -aurelio >. Acesso em: 24 ago. 2016; <http://www.redebrasilatual.com.br/ politica/2016/04/prisao-preventiva-para-pressionar-delacao-premiada-e-uma-forma-de-tortura-defende-jurista-6505.html>; Acesso em: 24 ago. 2016; <http://www.conjur.com.br/2014-nov-28/professores-criticam-parecer -prisao-preventiva-lava-jato>. Acesso em 24 ago. 2016; <http://politica.estadao.com.br/noticias/geral,prisao-preventiva-com-delacao-premiada-e-paude-arara-virtual-diz-sica,1642213>. Acesso em: 26 ago. 2016.

Sobre os riscos de uma atuação antiética por parte do Estado, por meio da justiça criminal negocial: "Não é difícil prever o que acontecerá caso essa tática de promover justiça vire algo de rotina (e se siga avalizando tal modo de agir) e as condenações pelos plea bargains virem indicadores de performance: notícias de uma acusação futura começam a chegar subrepticiamente para a imprensa, colocando o suspeito em situação difícil perante a sua família e a população. As acusações não precisam ser consistentes ou ter sério amparo probatório, mas a presunção pública de que o Procurador (ou Promotor) tem um caso ganha ares de verdade. O acusado, por sua vez, ouve de seu advogado 
De um lado, afirmar que houve coação por meio da prisão é o mesmo que afirmar que a prisão foi ilegal. Viu-se que, aos menos em tese, os fundamentos da prisão preventiva não se compatibilizam com a coação do acusado. Ademais, se a prisão preventiva retirasse do réu toda a sua autonomia, não apenas o acordo de colaboração premiada, mas toda a instrução processual deveria ser anulada sempre que o réu estivesse preso. De outro lado, a regulação da colaboração premiada trouxe mecanismos para impedir arbitrariedades por parte do aparato estatal, tais como a presença do advogado em todos os atos, a gravação das tratativas em meio audiovisual, o afastamento do juiz da fase de negociações, dentre outros.

Assim, a incompatibilidade entre prisão preventiva e colaboração premiada, se existente, surgiu na prática pela atuação dos operadores dos institutos. Se há um problema ético a ser combatido, ele não reside nos institutos em si, mas na atuação dos agentes responsáveis pela persecução penal. Condena-se a colaboração premiada, sugere-se a sua alteração legislativa, ou a sua extirpação do sistema, sem que se perceba que, na verdade, o problema é externo. É dizer: se problema há, ele não se encontra nos institutos em si. E essa advertência mostrase relevante porque não será a alteração dos institutos que permitirá solução ao pretenso problema ou abuso no uso da prisão processual. Para coibir possíveis ilegalidades no manejo de institutos que afetam a liberdade de locomoção do indivíduo, como a prisão preventiva, existe a via do habeas corpus, que permite a revisão do ato coator em todos os graus de jurisdição.

Quando se afirma que a prisão é ilegal, mesmo após a sua análise em todas as instâncias, afirma-se, na verdade, que todo o sistema de controle é ineficiente, ou que, deliberadamente, não coibiu ilegalidades

que virão inúmeras acusações e, mesmo infundadas, algumas prevalecerão. Começa, então, a vazar secretamente para a imprensa que o Procurador (ou Promotor) tem provas contra a família do acusado, que é ouvida em inquéritos ou investigações preliminares. O caso é teórico, mas qual seria a saída para o acusado? É desnecessário responder, embora seja o que se tem passado" (COUTINHO, Jacinto; CARVALHO, Edward Rocha de. Acordos de delação premiada e o conteúdo ético mínimo do Estado. Revista de Estudos Criminais, São Paulo, ano VI, n. 22, p. 75-84, abr./jun. 2006. p. 82). 
ocorridas na prática, seja pelo clamor social, seja por outros motivos obscuros, que só se pode imaginar, mas não comprovar.

Contudo, ao se transferir a crítica para os operadores do instituto, entra-se em uma zona obscura, em que não há certeza jurídica. Desconfia-se da idoneidade moral dos agentes estatais, mas não é possível controlar o pensamento de cada um dos envolvidos no acordo. Suspeita-se que medidas ilegais estão sendo tomadas, mas dificilmente elas serão comprovadas. A crítica que ora se apresenta pressupõe uma falência ética do Poder Judiciário. É como se não houvesse instância de controle que fosse confiável o suficiente para impedir que o réu sofra algum tipo de constrangimento indevido.

Todavia, não se pode perder de vista que, juridicamente, não é possível presumir a má-fé. Não se está, com isso, fechando os olhos para eventuais ilegalidades que, caso existentes, devem ser coibidas. Está-se apenas adequando a crítica à premissa básica do Direito: a má-fé não se presume, deve ser comprovada de parte a parte. Se for provado que o acusado foi coagido a colaborar, o acordo deve ser anulado. Arbitrariedades devem ser combatidas em cada caso, e não tratadas como regra.

\section{Possíveis soluções para o problema}

Como visto, os fundamentos previstos pelo art. 312 do CPP não permitem, em teoria, que a prisão preventiva seja utilizada como estímulo para a colaboração. Sustenta-se, todavia, que a coação estaria sendo feita de forma velada. Os fundamentos apresentados para a prisão serviriam apenas para camuflar a real finalidade da prisão, que seria coagir o acusado ou investigado a colaborar. Teme-se, ainda, que todas as instâncias de revisão estariam igualmente contaminadas, ao confirmarem a decisão que decretou a preventiva de forma indevida. Sob perspectiva diversa, sabe-se que o direito permite, apenas, a presunção de boa-fé, e não o contrário.

Como solucionar esse impasse? O receio de que a prisão preventiva seja utilizada de forma deturpada, aliado à impossibilidade de se desvendar o real propósito dos agentes responsáveis pela persecução penal, despertam a seguinte dúvida: diante da incerteza, a melhor solução seria proibir a celebração do acordo quando o investigado ou 
acusado estiver preso? Em outras palavras, se não é possível garantir que todas as prisões preventivas estejam estritamente vinculadas aos fundamentos do art. 312 do CPP, seria mais seguro proibir o acordo em todos os casos em que o réu estiver preso preventivamente?

Como apresentado em tópico anterior, essa é a ideia do Projeto de Lei n. 4.372/16, ainda em tramitação. Analisando-se o projeto após toda a reflexão acima apresentada, observa-se que, embora a sua intenção, à primeira vista, seja proteger os investigados ou acusados, é possível que ele acabe por prejudicá-los. Nos casos em que o conjunto probatório se revela mais desfavorável ao acusado, há grande probabilidade de ser decretada a segregação cautelar, pois os requisitos e fundamentos da prisão preventiva se tornam mais evidentes.

O réu preso cautelarmente é, assim, um dos maiores interessados na colaboração, não pela coação exercida pela prisão, mas pelo forte receio do resultado final da persecução penal. Nesse sentido, o Projeto de Lei, com o intuito de tutelar as garantias dos acusados ou investigados, poderia alcançar o efeito contrário: aqueles a quem mais interessaria a celebração do acordo ficariam impedidos de fazê-lo.

A Comissão de Segurança Pública e Combate ao Crime Organizado trouxe essa reflexão para o cenário político, ao afirmar que "impedir que os indivíduos presos possam celebrar acordo de colaboração premiada viola o princípio da isonomia" 56 , uma vez que impede o exercício de importante estratégia defensiva.

O problema, assim, não teria solução? Na verdade, as soluções já se encontram na lei. Existem mecanismos legais suficientes para a proteção do acusado, seja no tocante ao controle da prisão preventiva, seja em relação à regulação da colaboração premiada trazida pela Lei $12.850 / 2013$.

Caso todas essas disposições sejam aplicadas, é reduzido o risco de coação indevida do acusado. A grande questão é garantir que esse

56 BRASIL. Comissão de segurança pública e combate ao crime organizado. Parecer pela rejeição do Projeto de Lei n. 4.372, de 2016. Relator: Delegado Edson Moreira. Disponível em: <http://www.camara.gov.br/proposicoesWeb/prop_mostrarintegra;jsessionid=9B188C8C00057F8494AB5A8BDF3BB83A.proposicoesWeb2? codteor $=1485107 \&$ filename $=$ Parecer-CSPCCO-22-08-2016>. Acesso em: 7 set. 2016. 
controle seja realizado. Deve-se confiar nas instâncias de supervisão e submeter a elas todo tipo de conduta aparentemente ilegal. Caso se argumente que, ainda assim, as ilegalidades subsistirão, chega-se a um cenário juridicamente insolucionável: a falência do sistema. Não é nisso que se deve acreditar. A Defesa, além de criticar o sistema jurídico existente, deve utilizá-lo a seu favor, explorando todos os mecanismos legais que lhe são oferecidos. As pretendidas alterações legislativas podem acabar por enfraquecê-la, e não o contrário.

Em síntese, pretende-se mostrar que, em momentos de crise de legalidade, o que se deve buscar é a aplicação da lei, e não a sua alteração.

\section{ConClusões}

De todos os argumentos apresentados, observa-se, primeiramente, que não há um estudo estatístico completo, para que se possa atestar a existência de uma relação concreta de causa e efeito entre prisão e colaboração premiada, já que, como visto, no plano jurídico, tal vínculo não é admissível. Ao contrário, algumas análises estatísticas, ainda que não atualizadas, têm demonstrado que boa parte dos acordos de colaboração premiada foram firmados com investigados ou acusados soltos.

Verifica-se, ainda, que as críticas à colaboração premiada têm se restringido à sua utilização no âmbito da Operação Lava-jato, o que consiste em uma visão reducionista do problema. Aliás, reduzir a compreensão do instituto da colaboração premiada ao caso da Operação Lava-jato malfere, de um lado, a própria utilidade do caso penal como meio de estudo e, de outro lado, esvazia um instituto pensado de modo mais amplo como meio de obtenção de $\operatorname{prova}^{57}$ no enfrentamento da macrocriminalidade.

É certo que a Operação Lava-jato deu notoriedade à colaboração premiada, mas o instituto em estudo é muito mais amplo - é anterior à

57 O artigo adota o entendimento consolidado pelo plenário do Supremo Tribunal Federal, nos autos do Habeas Corpus $n^{\circ} 127.483$ /PR, que definiu a natureza jurídica da colaboração premiada como um meio de obtenção de prova. Para o aprofundamento da discussão, sugere-se a leitura de: MASSON, Cleber; MARÇAL, Vinícius. Crime organizado. 2 ed, São Paulo: Método, 2016. p. 121-124. 
Operação e irá permanecer vigente após o término dela. Não é possível, pois, formular conclusões, ou mesmo propor alterações legislativas, com base em uma visão tão estreita do problema.

A grande crítica que se pode fazer ao debate ora apresentado é o fato de que um problema pontual, supostamente ocorrido no âmbito de uma investigação, tem sido apresentado como um problema estrutural do instituto da colaboração premiada. Não se pode esquecer que as medidas adotadas com o intuito de mitigar supostas ilegalidades ocorridas na Operação Lava-jato terão reflexo em futuras investigações.

Como visto, a colaboração premiada se apresenta como importante estratégia defensiva, notadamente nos casos em que o acervo probatório é bastaste desfavorável ao acusado ou investigado. Nesses casos, é possível que o réu seja preso preventivamente, de forma legítima, se demonstrada, por exemplo, a gravidade concreta da sua conduta e preenchidos os demais requisitos do art. 312 do CPP.

Em um cenário como esse, não é a prisão preventiva, por si só, que irá estimular a colaboração premiada, mas a real probabilidade de que a persecução penal resulte em uma condenação à elevada pena privativa de liberdade.

Frise-se: o réu estaria preso preventivamente de forma legítima, pois preenchidos os requisitos legais. Nesses casos, é interessante para o réu colaborar. É uma estratégia, que a defesa pode optar por seguir, ou não, após analisar todos os elementos que pesam contra o réu. Retirar a possibilidade de o acusado (ou investigado) preso preventivamente colaborar significaria deixar aqueles que mais necessitam da colaboração sem essa importante alternativa.

A colaboração não deve ser encarada como algo negativo para a defesa, mas como uma opção que pode suavizar significativamente a reprimenda do acusado, que potencialmente seria condenado a penas elevadas, no regime fechado. Isso, porque, para que seja admitida a utilização da colaboração premiada, pressupõe-se que o réu esteja sendo acusado de crimes graves, com penas superiores a quatro anos, ou de caráter transnacional. ${ }^{58}$

58 Lei 12.850-2013 - Art. $1^{\circ}$ Esta Lei define organização criminosa e dispõe sobre a investigação criminal, os meios de obtenção da prova, infrações penais correlatas e 
A prisão também não pode ser tratada, de forma generalizada, como um ato condenável por parte do Estado. Não pode ser encarada, sempre, como uma coação indevida, ou um "ato de tortura", sob pena de se esquecer da sua real finalidade, que é resguardar a sociedade e a própria persecução penal. A prisão preventiva é, sim, medida excepcional, mas não é medida proibida, como se tem apresentado. O mais importante é analisar se, em cada caso, estavam realmente presentes os fundamentos da prisão preventiva.

Com base nisso, conclui-se que o verdadeiro problema na relação entre prisão preventiva e colaboração premiada não recai sobre os institutos em si, mas sobre os seus operadores. Tecnicamente, como se evidenciou, não há incompatibilidade entre prisão e colaboração. A prisão preventiva possui requisitos e fundamentos específicos, previstos pelo art. 312 do CPP, que, se observados, não autorizam a segregação como instrumento para forçar a colaboração. Em síntese, respeitadas as hipóteses de cabimento da prisão preventiva, não há como reduzir a prisão a um instrumento de coação, pois seus requisitos são incompatíveis com isso.

Constata-se, portanto, que, se há, na prática, uma relação de causa e efeito entre a prisão e a colaboração, é porque a finalidade da prisão preventiva está sendo deturpada. A mácula estaria, assim, nos operadores, e não nesse instrumento de obtenção de provas que, como visto, além de muito importante no combate da criminalidade organizada, foi devidamente regulado pela Lei 12.850/2013.

Se não se pode controlar a mentalidade dos operadores do instituto, a melhor solução seria, então, proibir, por meio de alteração legislativa, o acordo de colaboração premiada para todos os casos em que o colaborador está preso? Como visto, isso acabaria por prejudicar a pró-

o procedimento criminal a ser aplicado. $\S 1^{\circ}$ Considera-se organização criminosa a associação de 4 (quatro) ou mais pessoas estruturalmente ordenada e caracterizada pela divisão de tarefas, ainda que informalmente, com objetivo de obter, direta ou indiretamente, vantagem de qualquer natureza, mediante a prática de infrações penais cujas penas máximas sejam superiores a 4 (quatro) anos, ou que sejam de caráter transnacional. § $2^{\circ}$ Esta Lei se aplica também: I - às infrações penais previstas em tratado ou convenção internacional quando, iniciada a execução no País, o resultado tenha ou devesse ter ocorrido no estrangeiro, ou reciprocamente; II - às organizações terroristas, entendidas como aquelas voltadas para a prática dos atos de terrorismo legalmente definidos (Redação dada pela lei n ${ }^{\circ} 13.260$, de 2016). 
pria defesa, que se veria desmuniciada de uma importante alternativa de defesa, quando constado que existem fortes fundamentos e elementos de prova para a condenaçã̃o ${ }^{59}$.

A Lei já fornece os instrumentos necessários para a tutela dos direitos do colaborador. Supostos desvios ocorridos na prática não podem ser tratados como vícios estruturais do instituto. Se não há incompatibilidade em abstrato entre prisão preventiva e colaboração premiada, a alteração da lei não solucionará o problema - notadamente quando a mudança se baseia em premissa juridicamente equivocada: a má-fé dos agentes estatais.

\section{REFERÊNCIAS}

ARAS, Vladimir. Sétima crítica: a prisão preventiva do colaborador é usada para extorquir acordos de colaboração premiada. 13 maio 2015. Blog do Vlad. Disponível em: <https://blogdovladimir.wordpress.com/2015/05/13/setimacritica-a-prisao-preventiva-do-colaborador-e-usada-para-extorquir-acordos-decolaboracao-premiada/>. Acesso em 12 set. 2016.

ALSCHULER, Albert W. The changing plea bargaining debate. California Law Review, n. 69, p. 652-730, 1981. Disponível em: <http://scholarship.law.berkeley. edu $/$ cgi/viewcontent.cgi?article $=2238 \&$ context $=$ californialawreview $>$. Acesso em: 8 fev. 2017.

BADARÓ, Gustavo. Quem está preso pode delatar? 23 jun. 2015. JOTA. Disponível em: <http://jota.uol.com.br/quem-esta-preso-pode-delatar >. Acesso em 11 set. 2016.

BORRI, Luiz Antonio. Delação premiada do investigado/acusado preso cautelarmente: quando o Estado se transfigura em criminoso para extorquir a prova do investigado. Boletim IBCCRIM, São Paulo, ano 24, n. 285, p. 6-8.

59 Assim, divergimos parcialmente da conclusão alcançada por Luiz Flavio Borges D’Urso. Segundo o autor, a colaboração premiada não é um mal em si mesmo, com o que concordamos. Todavia, afirma que a prisão preventiva é incompatível com o manejo da colaboração: “Assim, o instituto da delação premiada não é um mal em si mesmo, até porque representa, na sua essência, uma alternativa para a defesa, todavia, é preciso aperfeiçoá-lo, e a proposta que apresentamos é a proibição da oportunidade da delação premiada para aquele que se encontra preso cautelarmente, pois dessa forma se estaria preservando a obrigatória voluntariedade, que hoje é tão questionada no Brasil." (D’URSO, Luiz Flavio Borges. Delação premiada: proibição para quem está preso. Revista Magister de Direito Penal e Processual Penal, v. 11, n. 66, p. 64-66, 2015). 
BOTTINO, Thiago. Colaboração premiada e incentivos à cooperação no processo penal: uma análise crítica dos acordos firmados na "Operação Lava Jato". Revista Brasileira de Ciências Criminais, São Paulo, v. 24, n. 122, p. 359-390, ago. 2016.

BRANDALISE, Rodrigo da Silva. Justiça Penal Negociada. Curitiba: Juruá, 2014. BUSATO, Paulo César; BITENCOURT, Cezar Roberto. Comentários à Lei de Organização Criminosa - Lei 12.850/2013. São Paulo: Saraiva, 2014.

CANÁRIO, Pedro. Professores criticam parecer sobre prisões preventivas na "lava jato": delação forçada. 18 nov. 2016. Consultor Jurídico. Disponível em: <http:// www.conjur.com.br/2014-nov-28/professores-criticam-parecer-prisaopreventiva-lava-jato>. Acesso em 24 ago. 2016.

CASARA, Rubens RR; MELCHIOR, Antonio Pedro. Teoria do Processo Penal Brasileiro - dogmática e crítica: conceitos fundamentais. v. I. Rio de Janeiro: Lumen Juris, 2013.

COUTINHO, Jacinto N. Miranda. A Lide e o Conteúdo do Processo Penal. Curitiba: Juruá, 1989.

COUTINHO, Jacinto; CARVALHO, Edward Rocha de. Acordos de delação premiada e o conteúdo ético mínimo do Estado. Revista de Estudos Criminais, São Paulo, ano VI, n. 22, p. 75-84, abr./jun. 2006.

DELLAGNOL, Deltan. Lava Jato não usa prisões para obter colaboração de réus. 17 nov. 2015. UOL notícias Opinião. Disponível em: <http://noticias.uol. com.br/opiniao/coluna/2015/11/17/lava-jato-nao-usa-prisoes-para-obtercolaboracao-de-reus.htm>. Acesso em: 30 ago. 2016.

DERVAN, Lucian E.; EDKINS, Vanessa. The Innocent Defendant's Dilemma: An Innovative Empirical Study of Plea Bargaining's Innocence Problem. Journal of Criminal Law and Criminology, v. 103, n. 1, p. 01-48, mai./2013. Disponível em: $<$ http://scholarlycommons.law.northwestern.edu/cgi/viewcontent.cgi?article $=1000 \&$ context $=$ jclc $>$. Acesso em: 7 fev. 2017 .

D’URSO, Luiz Flavio Borges. Delação premiada: proibição para quem está preso. Revista Magister de Direito Penal e Processual Penal, v. 11, n. 66, p. 64-66, 2015.

ESPÍNOLA FILHO, Eduardo. Código de Processo Penal brasileiro anotado. 4. ed. Vol. V, Rio de Janeiro: Editor Borsoi, 1954.

HASSEMER, Winfried. Introdução aos fundamentos do Direito Penal. Trad. Pablo Rodrigo Alflen da Silva. Porto Alegre: Sérgio Fabris Editor, 2005.

JARDIM, Afrânio Silva, entrevista disponível em: <http://www.epsjv.fiocruz. $\mathrm{br} /$ noticias/entrevista/punir-e-importante-mas-nao-a-qualquer-preco $>$. Acesso em: 23 set. 2016. 
LANGBEIN, John H. Torture and Plea Bargaining. The University of Chicago Law Review, vol. 46, n. 1, p. 3-22, 1978. Disponível em: < http://chicagounbound.uchicago. edu/cgi/viewcontent.cgi? article=4154\&context=uclrev>. Acesso em: 7 fev. 2017.

LIMA, Helder. Prisão preventiva para obter delação premiada é tortura, defende jurista: lava jato. 07 abr. 2016. Rede Brasil Atual. Disponível em: <http://www. redebrasilatual.com.br/politica/2016/04/prisao-preventiva-para-pressionardelacao-premiada-e-uma-forma-de-tortura-defende-jurista-6505.html>. Acesso em: 24 ago. 2016.

LIMA, Renato Brasileiro de. Código de Processo Penal Comentado. Salvador: Juspodvim, 2016.

LOPES, Elizabeth. Prisão preventiva com delação premiada é pau de arara virtual, diz Sica. 01 mar. 2015. Estadão Poítica. Disponível em: < http://politica.estadao. com.br/noticias/geral,prisao-preventiva-com-delacao-premiada-e-pau-dearara-virtual-diz-sica,1642213>. Acesso em: 26 ago. 2016.

LOPES JR., Aury. Direito Processual Penal. 10 ed. São Paulo: Saraiva, 2013.

MALAN, Diogo. Notas sobre a investigação e prova da criminalidade econômicofinanceira organizada. Revista Brasileira de Direito Processual Penal, Porto Alegre, vol. 2, n. 1, p. 213 - 238, 2016. http://dx.doi.org/10.22197/rbdpp.v2i1.22

MASSON, Cleber; MARÇAL, Vinícius. Crime organizado. São Paulo: Método, 2015.

MENDES, Soraia da Rosa; BARBOSA, Kássia Cristina de Sousa. Anotações sobre o Requisito da Voluntariedade e o Papel do/a Juiz/a em acordos de colaboração premiada envolvendo investigados/as e/ou réus/rés presos/as provisoriamente. In: MENDES, Soraia da Rosa (org.). A delação/colaboração premiada em perspectiva. Brasília: IDP, 2016. p. 72-89.

RODAS, Sérgio. Delação premiada é ato de covardia, afirma ministro do STF Marco Aurélio: coação ilegal. 16 ago. 2016. Consultor Jurídico. Disponível em: <http://www.conjur.com.br/2016-ago-12/delacao-premiada-ato-covardiaafirma-ministro-marco-aurelio>. Acesso em: 24 ago. 2016.

ROSA, Alexandre Morais da; LOPES JR., Aury. Com delação premiada e pena negociada, Direito Penal também é Lavado a Jato. Disponível em: <http://www. conjur.com.br/2015-jul-24/limite-penal-delacao-premiada-direito-penal tambem-lavado-jato>. Acesso em: 28 ago. 2016.

SANTOS, Marcos P. Colaboração (delação) premiada. Salvador: JusPodivm, 2016.

SILVEIRA, Marco Aurélio Nunes da. A ação processual penal entre política e constituição: outra teoria para o direito processual penal. Disponível em: $<$ http://acervodigital.ufpr.br/bitstream/handle/1884/28008/R\%20 -\%20T\%20-\%20MARCO\%20AURELIO\%20NUNES\%20DA\%20SILVEIRA. pdf? sequence=1\&isAllowed=y>. Acesso em: 8 fev. 2017. 
SUXBERGER, Antonio Henrique Graciano. Colaboração premiada e a adoção da oportunidade no exercício da ação penal pública. In: MENDES, Soraia da Rosa (org.). A delação/colaboração premiada em perspectiva. Brasília: IDP, 2016.

SUXBERGER, Antonio Henrique Graciano; GOMES FILHO, Dermeval Faria. Funcionalização e expansão do direito penal: o Direito Penal negocial. Revista de Direito Internacional, Brasília, v. 13, n.1, 2016, p. 377-39. http://dx.doi. org/10.5102/rdi.v13i1.3976ht

UNITED STATES GOVERNMENT. Federal Rules of Criminal Procedure. Effective March 21, 1946, as amended do December 1, 2015. Disponível em <https:// judiciary.house.gov/wp-content/uploads/2016/02/Criminal2015.pdf>. Acesso em: 12 dez. 2016.

VASCONCELLOS, Vinicius Gomes de. Barganha e Justiça Criminal Negocial: análise das tendências de expansão dos espaços de consenso no processo penal brasileiro. São Paulo: IBCCRIM, 2015.

\section{Dados do processo editorial}

(http://www.ibraspp.com.br/revista/index.php/RBDPP/about/editorialPolicies)

- Recebido em: 27/12/2016

- Controle preliminar e verificação de plágio: 27/12/2016

- Avaliação 1: 04/01/2017

- Avaliação 2: 16/01/2017

- Decisão editorial preliminar: 25/01/2017

- Retorno rodada de correções 1:08/02/2017

- Decisão editorial 2: 08/02/2017

- Retorno rodada de correções 2: 09/02/2017

- Decisão editorial final: 09/02/2017

\section{Equipe editorial envolvida}

- Editor-chefe: 1 (VGV)

- Editora-associada: 1 (SRM)

- Revisores: 2

\section{COMO CITAR ESTE ARTIGO:}

SUXBERGER, Antonio H. G.; MELLO, Gabriela S. J. V. A voluntariedade da colaboração premiada e sua relação com a prisão processual do colaborador. Revista Brasileira de Direito Processual Penal, Porto Alegre, vol. 3, n. 1, p. 189-224, jan./abr. 2017. https://doi.org/10.22197/rbdpp.v3i1.40

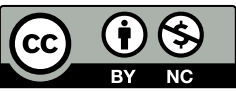

Esta obra está licenciada com uma Licença Creative Commons Atribuição-NãoComercial 4.0 Internacional. 